\title{
Single nucleotide polymorphisms (SNPs) of ERCC2, hOGG1, and $X R C C 1$ DNA repair genes and the risk of triple-negative breast cancer in Polish women
}

\author{
Beata Smolarz • Marianna Makowska • \\ Dariusz Samulak • Magdalena M. Michalska • \\ Ewa Mojs • Maciej Wilczak • Hanna Romanowicz
}

Received: 28 October 2013 / Accepted: 22 November 2013 / Published online: 9 January 2014

(C) The Author(s) 2014. This article is published with open access at Springerlink.com

\begin{abstract}
Triple-negative breast cancer (TNBC) refers to about $15-20 \%$ of all breast cancer cases. It is characterized by worse clinical outcome, poor prognosis, and absence of prognostic indicators. Several polymorphisms in the nucleotide excision repair (NER) and base excision repair (BER) gene have been extensively studied in association with various human cancers. The aim of this study was to evaluate the role of the hOGG1-Ser326Cys (rs13181), XRCC1-Arg194Trp (rs1799782), and ERCC2-Lys751Gln (rs13181) gene
\end{abstract}

B. Smolarz $(\bowtie)$

Laboratory of Molecular Genetics, Department of Pathology,

Institute of Polish Mother's Memorial Hospital, Rzgowska 281/289,

93-338 Lodz, Poland

e-mail: smolbea@wp.pl

M. Makowska

Regional Hospital in Lodz, Łódź, Poland

D. Samulak $\cdot$ M. M. Michalska

Department of Obstetrics and Gynaecology, Regional Hospital in Kalisz, Kalisz, Poland

D. Samulak

Cathedral of Mother's and Child's Health, Poznan University of

Medical Sciences, Poznań, Poland

D. Samulak

Clinic of Gynaecological Surgery, Poznan University of Medical

Sciences, Poznań, Poland

E. Mojs

Department of Clinical Psychology, Poznan University of Medical

Sciences, Poznań, Poland

M. Wilczak

Department of Medical Education, Poznan University of Medical

Sciences, Poznan, Poland

H. Romanowicz

University of Computer Sciences and Skills, Lodz, Poland polymorphisms with clinical parameters and the risk for development of triple-negative breast cancer. Our research included 70 patients with TNBC and 70 healthy controls. Gene polymorphisms were genotyped by the PCR-RFLP (restriction fragment length polymorphism) method. The genotype distributions were contrasted by the chi-square test, and the significance of the polymorphism was assessed by multiple logistic regression producing odds ratios (ORs) and $95 \%$ confidence intervals (CIs). In the present work, a relationship was identified between ERCC2-Lys751Gln polymorphism and the incidence of triple-negative breast cancer. An association was observed between triple-negative breast carcinoma occurrence and the presence of $\mathrm{Gln} / \mathrm{Gln}$ genotype $(\mathrm{OR}=5.71$ (2.12-5.43), $p=$ 0.0007). A tendency for an increased risk of TNBC was detected with the occurrence of $751 \mathrm{Gln}$ allele of ERCC2 polymorphism. No significant associations between Ser326Cys and Arg194Trp genotype and TNBC were observed. We suggest that the Lys751Gln polymorphism of the ERCC2 gene may be risk factors for triple-negative breast cancer development in Polish women.

Keywords Triple-negative breastcancer $\cdot E R C C 2$ - hOGG1 · $X R C C 1 \cdot$ Genes · Genetic polymorphism

\section{Introduction}

Carcinoma of the breast is the most common cause of cancer deaths among women worldwide. Despite a decline in incidence since 2003, in 2008, nearly 1,400,000 new cases of breast cancer were diagnosed, and there were about 450,000 women who died from this disease $[1,2]$.

Currently, more women survive due to earlier diagnosis and better therapy. Breast cancer classification is in constant evolution, as advances in molecular pathology as well as 
immunohistochemical staining allow researchers to define the molecular heterogeneity of different disease subtypes and to guide the selection of appropriate treatment.

The triple-negative phenotype, defined as the lack of estrogen receptor (ER), progesterone receptor (PR), and human epidermal growth factor receptor-2 (HER-2) expression, represents approximately $15-20 \%$ of breast cancer cases and has a worse clinical outcome and prognosis than other breast cancer subtypes [2-6]. As a group, triplenegative breast cancer (TNBC) is frequently associated with development of distant metastasis, shorter survival, and a higher mortality rate than other disease subtypes. Most recurrences are observed during the first and third years after therapy, and most deaths take place in the first 5 years, even after a strict therapeutic regimen. The triple negativity represents an independent factor for poor prognosis evaluation for breast cancer [2-6].

Breast cancer may be associated with the high exposure of breast tissue to exo- and endogenous estrogens. Estrogens produce DNA bulky adducts and oxidative base damages which are removed in nucleotide excision repair (NER) and base excision repair (BER) systems. The reaction of breast cells to DNA damage may be very important for their susceptibility to cancer development. This reaction is executed mainly by DNA repair, which can be modulated by the variability in the genes encoding DNA repair proteins.

A NER system removes short DNA oligonucleotides containing a damaged base [7]. NER recognizes bulky lesions caused by carcinogenic compounds and covalent linkages between adjacent pyrimidines resulting from UV exposure. NER is further classified into global genome repair (GGNER) that occurs everywhere in the genome and transcription-coupled repair (TCR), which removes lesions in the transcribed strand of active genes. NER is a multistep process involving multiple proteins such as ERCC1, ERCC2, ERCC3, ERCC4, PCNA, RPA, XPA, and p53.

BER is critically important for repairing base damage induced by reactive oxygen species (ROS). BER corrects small DNA alterations that do not distort the overall structure of DNA helix, such as oxidized bases, or incorporation of uracil. BER is initiated by DNA glycosylases, which cleave $\mathrm{N}$-glycosylic bond of damaged bases leaving apurinic/ apyrimidinic site (AP site) $[8,9]$.

A damaged base is recognized by a specific glycosylase, which cleaves the bond between the base and sugar, creating an abasic site, which is cleaved by an endonuclease. Resulting gap is filled by pol $\beta$, and the remaining nick is sealed by DNA ligase LIG1 or LIG3 complexed with XRCC1.

Because NER and BER are involved in removing a substantial number of DNA damages, which can contribute to the genome instability, it is reasonable to check whether variability in the genes coding for BER and NER products may be associated with TNBC.
In the present work, we analyzed an association between TNBC and three SNPs occurring in two BER and NER genes: hOGG1-Ser326Cys (rs 13181), XRCC1-Arg194Trp (rs1799782) and ERCC2-Lys751Gln (rs13181), respectively. These polymorphisms have been correlated with various cancers [10-24], but little is known about their association with TNBC.

\section{Materials and methods}

\section{Patients}

In the present study, paraffin-embedded tumor tissues were obtained from 70 women with triple-negative breast carcinoma, treated at the Department of Oncology, Institute of Polish Mother's Memorial Hospital, Lodz, Poland, between 2000 and 2013. Clinical data for the patients and histological data were registered. The age of the patients ranged from 36 to 68 years (mean age $46.2 \pm 10.12$ ). The median follow-up of patients at the time of analysis was 38 months (range 2-70 months). The average tumor size was $20 \mathrm{~mm}$ (range $17-32 \mathrm{~mm}$ ). All the tumors were graded by a method, based on the criteria of Scarf-Bloom-Richardson. There were 20 tumors of stage I, 45 of stage II, and 5 of stage III in total. The demographic data and the pathologic features of the patients are summarized in Table 1. Samples from age-matched, cancer-free women $(n=$ $70)$ served as the control (mean age $45.41 \pm 18.21$ ). Control samples that consisted of DNA were extracted from normal breast tissue. Normal breast specimens were obtained from

Table 1 Characteristics of the study population $(n=70)$ triple-negative breast cancer patients

Triple-negative breast cancer patients, $n(\%)$

$\begin{array}{lr}\text { Scarf-Bloom-Richardson stage } & \\ \text { I } & 20(29) \\ \text { II } & 45(64) \\ \text { III } & 5(7) \\ \text { Tumor size grade } & \\ \text { T1 } & 8(11) \\ \text { T2 } & 40(57) \\ \text { T3 } & 18(26) \\ \text { T4 } & 4(6) \\ \text { Lymph node status } & \\ \text { N0 } & 32(46) \\ \text { N1 } & 12(17) \\ \text { N2 } & 14(20) \\ \text { N3 } & 7(10) \\ \text { N4 } & 5(7)\end{array}$


patients who had undergone biopsy for benign lesions. The study was approved by the Local Ethics Committee of the Institute of Polish Mother's Memorial Hospital, Lodz, Poland, and each patient gave a written consent.

\section{DNA isolation}

The cancerous and noncancerous breast tissue samples were fixed routinely in formaldehyde, embedded in paraffin, cut into thin slices, and stained with hematoxylin/eosin for pathological examination. DNA for analysis was obtained from an archival pathological paraffin-embedded tumor and noncancerous breast samples which were deparaffinized in xylene and rehydratated in ethanol and distilled water. In order to ensure that the chosen histological material is representative for cancerous and noncancerous tissue, every tissue sample qualified for DNA extraction was initially checked by a pathologist. DNA was extracted from the material using commercially available QIAamp Kit (Qiagen $\mathrm{GmbH}$, Hilden, Germany) DNA purification kit according to the manufacturer's instruction.

\section{Determination of ERCC2 genotype}

Polymorphism Lys751Gln of the ERCC2 gene was determined by PCR-RFLP, using primers (forward 5'-CTGCTC AGCCTGGAGCAGC-3' and reverse 5'-ACTGTCACTAGT CTCACCAG-3'). The PCR was carried out in a PTC-100 TM (MJ Research, INC) thermal cycler. PCR amplification was performed in the final volume of $25 \mu$ of reaction mixture, which contained $100 \mathrm{ng}$ of genomic DNA, $0.2 \mu \mathrm{mol}$ of each primer (ARK Scientific GmbH Biosystems, Darmstad, Germany), $2.5 \mathrm{mM}$ of $\mathrm{MgCl}_{2}, 1 \mathrm{mM}$ of dNTPs, and $1 \mathrm{U}$ of Taq polymerase (Qiagen $\mathrm{GmbH}$, Hilden, Germany). PCR cycle conditions were the following: $95^{\circ} \mathrm{C}$ for $30 \mathrm{~s}, 62{ }^{\circ} \mathrm{C}$ for $30 \mathrm{~s}$, and $72{ }^{\circ} \mathrm{C}$ for $30 \mathrm{~s}$, repeated in 35 cycles. PCR products were electrophoresed in a $2 \%$ agarose gel and visualized by ethidium bromide staining. The cleavage with Pst $\mathrm{I}$ (Fermentas, Vilnius, Lithuania) produced fragments of 161, 161/120/41, and 120/41 bp corresponding to the Lys/Lys, Lys/ Gln, and $\mathrm{Gln} / \mathrm{Gln}$ genotypes of the $E R C C 2$ gene, respectively.

\section{Determination of hOGG1 genotype}

Polymorphism Ser326Cys of the $h O G G 1$ gene was determined by PCR-RFLP, using primers (5'-GGAAGGTGCT TGGGGAAT- ${ }^{\prime}$ and 5'-ACTGTCACTAGTCTCACCAG$\left.3^{\prime}\right)$. The $25-\mu \mathrm{L}$ PCR mixture contained about $100 \mathrm{ng}$ of DNA, $12.5 \mathrm{pmol}$ of each primer, $0.2 \mathrm{mmol} / \mathrm{L}$ of dNTPs, $2 \mathrm{mmol} / \mathrm{L}$ of $\mathrm{MgCl}_{2}$, and $1 \mathrm{U}$ of Taq DNA polymerase. PCR products were electrophoresed in a $2 \%$ agarose gel and visualized by ethidium bromide staining. Only one 100-bp fragment was seen in subjects with the Cys/Cys genotype. In subjects with the Ser/Cys genotype, two bands of 100 and
$200 \mathrm{bp}$ were seen, whereas in those subjects homozygous for the Ser variant (Ser/Ser), only one 200-bp PCR fragment is seen. All PCR was carried out in a DNA thermal cycler (GeneAmp PCR System 2400; Perkin-Elmer, Norwalk, CT, USA). After an initial denaturation at $95^{\circ} \mathrm{C}$ for $5 \mathrm{~min}, 35 \mathrm{cy}$ cles of amplification with denaturation at $95{ }^{\circ} \mathrm{C}$ for $30 \mathrm{~s}$, annealing at $56^{\circ} \mathrm{C}$ for $30 \mathrm{~s}$, and extension at $72{ }^{\circ} \mathrm{C}$ for $30 \mathrm{~s}$ were performed, followed by a final extension step of $7 \mathrm{~min}$ at $72{ }^{\circ} \mathrm{C}$. The PCR product was digested overnight with $1 \mathrm{U}$ of Sat I (Fermentas, Vilnius, Lithuania) at $37{ }^{\circ} \mathrm{C}$.

\section{Determination of XRCC1 genotype}

Polymorphism Arg194Trp of the XRCC1 gene was determined by PCR-RFLP, using primers (forward 5'-GCCCGTCCCAGG TA-3', reverse 5'-AGCCCCAAGACCCTTTCACT-3').

The PCR was carried out in a PTC-100 TM (MJ Research, Inc.) thermal cycler. PCR amplification was performed in the final volume of $25 \mu \mathrm{l}$ of reaction mixture, which contained $100 \mathrm{ng}$ of genomic DNA, $0.2 \mu \mathrm{mol}$ of each primer (ARK Scientific GmbH Biosystems, Darmstad, Germany), $2.5 \mathrm{mM}$ of $\mathrm{MgCl} 2,1 \mathrm{mM}$ of dNTPs, and $1 \mathrm{U}$ of Taq Polymerase (Qiagen GmbH, Hilden, Germany). PCR cycle conditions were the following: $95{ }^{\circ} \mathrm{C}$ for $30 \mathrm{~s}, 62{ }^{\circ} \mathrm{C}$ for $30 \mathrm{~s}$, and $72{ }^{\circ} \mathrm{C}$ for $40 \mathrm{~s}$, repeated in 35 cycles. After digestion with $P v u \mathrm{II}$ (New England Biolabs, Ipswich, MA, USA) for $4 \mathrm{~h}$ at $37^{\circ} \mathrm{C}$, the samples were run on $2 \%$ agarose gel and visualized by ethidium bromide staining. The cleavage of the XRCC1 fragment with $P v u$ II (New England Biolabs, Ipswich, MA, USA) produced bands of 292/174/21, 313/292/174/21, and 313/174 bp corresponding to the Arg/Arg, Arg/Trp, and Trp/ Trp genotypes, respectively.

\section{Statistical analysis}

The allelic frequencies were estimated by gene counting, and the genotypes were scored. The observed numbers of each $h O G G 1$, $X R C C 1$, and $E R C C 2$ genotype were compared with those expected for a population in Hardy-Weinberg equilibrium by using the chi-square test. Genotype frequencies in the study cases and the controls were compared by the chi-square test. Genotypespecific risks were estimated as odds ratios (ORs) with associated $95 \%$ confidence intervals (CIs) by unconditional logistic regression. $p$ values $<0.05$ were considered significant. All the statistical analyses were performed, using the STATISTICA 6.0 software (Statsoft, Tulsa, OK, USA).

\section{Results}

All the recruited TNBC samples $(n=70)$ and control $(n=70)$ were successfully genotyped for the ERCC2, hOGG1, and $X R C C 1$ polymorphisms. From the PCR analysis, all patients 
Table 2 Distribution of Lys/Lys, Lys/Gln, and Gln/Gln genotypes and frequencies of the Lys and Gln alleles of the ERCC2 gene in patients with triplenegative breast cancer and controls

\begin{tabular}{|c|c|c|c|c|c|c|}
\hline \multirow[t]{2}{*}{ ERCC2-Lys751Gln } & \multicolumn{2}{|c|}{ TNBC patients $(n=70)$} & \multicolumn{2}{|c|}{ Controls $(n=70)$} & \multirow[t]{2}{*}{ OR $(95 \% \text { CI })^{\mathrm{a}}$} & \multirow[t]{2}{*}{$p^{\mathrm{b}}$} \\
\hline & Number & $(\%)$ & Number & $(\%)$ & & \\
\hline Lys/Lys & 10 & 14 & 16 & 23 & 1.00 Ref & \\
\hline Lys/Gln & 10 & 14 & 40 & 57 & $0.40(0.14-1.14)$ & 0.144 \\
\hline $\mathrm{G} \ln / \mathrm{Gln}$ & 50 & 72 & 14 & 20 & $5.71(2.12-5.34)$ & 0.0007 \\
\hline Lys & 30 & 21 & 72 & 51 & $1.00 \mathrm{Ref}$ & \\
\hline Gln & 110 & 79 & 68 & 49 & $3.88(2.30-6.55)$ & $<0.0001$ \\
\hline
\end{tabular}

Data in boldface are statistically significant

${ }^{a}$ Crude odds ratio (confidence interval at $95 \%$ )

${ }^{\mathrm{b}}$ Chi-square

were classified into three genotypes of the $E R C C 2$ polymorphism: Lys/Lys, Lys/Gln and Gln/Gln, and hOGG1 polymorphism; Ser/Ser, Ser/Cys and Cys/Cys, and XRCC1 polymorphism; and Arg/Arg, Arg/Trp, and Trp/Trp genotypes.

It can be seen from Table 2 that there are significant differences in the frequency of ERCC2-Lys751 Gln genotypes $(p<0.05)$ between the two investigated groups. A weak association was observed between triple-negative breast carcinoma occurrence and the presence of Gln/Gln genotypes. Variant $751 \mathrm{Gln}$ allele of $E R C C 2$ increased cancer risk. In case of the Lys $751 \mathrm{Gln}$ polymorphism of $E R C C 2$ gene, the distribution of the genotypes in the patients differed significantly from the one expected from the Hardy-Weinberg equilibrium $(p<$ $0.05)$.

No statistically significant differences were observed in genotype frequencies of $h O G G 1$-Ser326Cys and XRCC1Arg194Trp polymorphisms between the control group and the TNBC patients (see Tables 3 and 4). Among the patients, all genotype distributions did not differ significantly $(p>0.05)$ from those expected from the Hardy-Weinberg equilibrium.

Histological grading was related to ERCC2-Lys751Gln, hOGG1-Ser326Cys, and the XRCC1-Arg194Trp polymorphisms. Histological stages were evaluated in all the cases $(n=70)$. There were 20 cases in stage I, 45 cases in stage II, and 5 cases in stage III. Stages II and III were accounted together for statistical analysis (see Table 5). No differences were observed in those groups regarding either ERCC2-Lys751Gln genotype or allele distributions. Some correlation was observed between the hOGG1-Ser326Cys and XRCC1 -Arg194Trp polymorphisms and TNBC invasiveness. An increase was observed regarding Ser/Cys heterozygotes frequency (OR 2.42; $95 \% \mathrm{CI} 0.58-9.99, p=0.177$ ) and Arg/Trp heterozygotes (OR 1.89; $95 \%$ CI 0.54-6.57, $p=$ 0.479 ) in stage I patients, according to the Scarf-BloomRichardson classification. That increase was, however, not statistically significant $(p>0.05)$.

Table 6 shows the distribution of genotypes and the frequency of alleles in patients with different tumor size. A tendency for an increased risk of TNBC was observed with the occurrence of $751 \mathrm{Gln}$ allele of ERCC2 polymorphism. That increase was statistically significant $(p<0.05)$. There were no differences either in the distribution of genotypes or the frequency of alleles in the group of patients with $(\mathrm{N}+)$ and without $\left(\mathrm{N}^{-}\right)$lymph node metastases (Table 6).

\section{Discussion}

The aim of the present study was to evaluate the associations between the risk of TNBC and polymorphisms in the genes,
Table 3 Distribution of Ser/Ser, Ser/Cys, and Cys/Cys genotypes and frequencies of the Arg and His alleles of the $h O G G 1$ gene in patients with triple-negative breast cancer and controls

${ }^{\text {a }}$ Crude odds ratio (confidence interval at $95 \%$ )

${ }^{\mathrm{b}}$ Chi-square

\begin{tabular}{|c|c|c|c|c|c|c|}
\hline \multirow[t]{2}{*}{ hOGG1-Ser326Cys } & \multicolumn{2}{|c|}{ TNBC patients $(n=70)$} & \multicolumn{2}{|c|}{ Controls $(n=70)$} & \multirow[t]{2}{*}{ OR $(95 \% \mathrm{CI})^{\mathrm{a}}$} & \multirow[t]{2}{*}{$p^{\mathrm{b}}$} \\
\hline & Number & $(\%)$ & Number & $(\%)$ & & \\
\hline Ser/Ser & 16 & 23 & 16 & 23 & 1.00 Ref & \\
\hline Ser/Cys & 39 & 56 & 38 & 54 & $1.02(0.45-2.34)$ & 0.888 \\
\hline Cys/Cys & 15 & 21 & 16 & 23 & $0.93(0.34-2.51)$ & 0.887 \\
\hline Ser & 71 & 51 & 70 & 50 & 1.00 Ref & \\
\hline Cys & 69 & 49 & 70 & 50 & $0.97(0.60-1.55)$ & 1.000 \\
\hline
\end{tabular}


Table 4 Distribution of Arg/Arg, Arg/Trp, and Trp/Trp genotypes and frequencies of the Thr and Met alleles of the XRCC1 gene in patients with triple-negative breast cancer and controls

${ }^{a}$ Crude odds ratio (confidence interval at $95 \%$ )

${ }^{\mathrm{b}}$ Chi-square

\begin{tabular}{|c|c|c|c|c|c|c|}
\hline \multirow[t]{2}{*}{ XRCC1-Arg194Trp } & \multicolumn{2}{|c|}{ TNBC patients $(n=70)$} & \multicolumn{2}{|c|}{ Controls $(n=70)$} & \multirow[t]{2}{*}{ OR $(95 \% \mathrm{CI})^{\mathrm{a}}$} & \multirow[t]{2}{*}{$p^{\mathrm{b}}$} \\
\hline & Number & $(\%)$ & Number & $(\%)$ & & \\
\hline Arg/Arg & 20 & 29 & 15 & 21 & 1.00 Ref & \\
\hline Arg/Trp & 31 & 44 & 39 & 56 & $0.59(0.26-1.35)$ & 0.301 \\
\hline $\operatorname{Trp} / \operatorname{Trp}$ & 19 & 27 & 16 & 23 & $0.89(0.34-2.28)$ & 1.000 \\
\hline Arg & 71 & 51 & 69 & 49 & 1.00 Ref & \\
\hline $\operatorname{Trp}$ & 69 & 49 & 71 & 51 & $0.95(0.59-1.50)$ & 0.920 \\
\hline
\end{tabular}

encoding for key proteins of BER and NER. In the present work, we analyzed three single nucleotide polymorphisms of the XRCC1, hOGG1, and ERCC2 DNA repair genes and tested the association between the distributions of their genotypes with TNBC.

ERCC2-Lys751Gln, hOGG1-Ser326Cys, and the XRCC1 -Arg194Trp polymorphisms have been shown to have functional significance and may be in part responsible for the interindividual difference in capacity of DNA repair in the general population and for low DNA repair efficacy in patients with various cancers [25-28].

In the presented study, ERCC2-Gln/Gln genotype was associated with an elevated risk of TNBC in the Polish population. There was a 5.71-fold increased risk of TNBC for ERCC2-Gln/Gln genotype carriers, compared with subjects with the ERCC2-Lys/Lys and Lys/Gln genotypes, respectively. We have also found that ERCC2-Lys751Gln polymorphism was related to tumor size. This result may suggest major contribution of the Lys751Gln polymorphism of the ERCC2 gene in cancer development, but more studies performed on larger population are needed to draw a final conclusion.

It is known that the Gln/Gln homozygous variant of the $E R C C 2$ gene has been associated with an increased risk of lung, skin, bladder, and breast cancer [20, 21, 29, 30].

The role of ERCC2 -Lys751Gln polymorphisms and breast cancer development is still unknown. To date, no studies have addressed the association between alterations in this region of the ERCC2 gene and TNBC. Because a proper functioning of the ERCC2 gene is important for the genomic stability, its alternations may be associated with higher cancer susceptibility.

Breast cancer is estrogen related. Estrogen mediates cellular growth and differentiation in tissues such as the mammary
Table 5 Dependence of genotypes and frequencies of $E R C C 2$, $h O G G 1$, and $X R C C 1$ gene polymorphism alleles on tumor stage in triple-negative breast cancer patients $(n=70)$

${ }^{\text {a }}$ According to the Scarf-BloomRichardson criteria

${ }^{\mathrm{b}}$ Crude odds ratio (confidence interval at $95 \%$ )

${ }^{\mathrm{c}}$ Chi-square

\begin{tabular}{|c|c|c|c|c|}
\hline \multirow[b]{2}{*}{ Stage $^{\mathrm{a}}$} & \multicolumn{2}{|c|}{ Triple-negative breast cancer patients } & \multirow[t]{2}{*}{ OR $(95 \% \mathrm{CI})^{\mathrm{b}}$} & \multirow[t]{2}{*}{$p^{\mathrm{c}}$} \\
\hline & $\begin{array}{l}\text { I }(n=20) \\
\text { Number }(\%)\end{array}$ & $\begin{array}{l}\mathrm{II}+\mathrm{III}(n=50) \\
\text { Number }(\%)\end{array}$ & & \\
\hline \multicolumn{5}{|c|}{ ERCC2-Lys751Gln } \\
\hline Lys/Lys & $5(25)$ & $5(10)$ & $1.00 \mathrm{Ref}$ & \\
\hline Lys/Gln & $2(10)$ & $8(16)$ & $0.25(0.03-1.81)$ & 0.175 \\
\hline $\mathrm{Gln} / \mathrm{Gln}$ & $13(65)$ & $37(74)$ & $0.35(0.08-1.41)$ & 0.129 \\
\hline Lys & $12(30)$ & $18(18)$ & $1.00 \operatorname{Ref}$ & \\
\hline Gln & $28(70)$ & $82(82)$ & $0.51(0.21-1.19)$ & 0.182 \\
\hline \multicolumn{5}{|c|}{ hOGG1-Ser326Cys } \\
\hline Ser/Ser & $3(15)$ & $13(26)$ & $1.00 \mathrm{Ref}$ & \\
\hline Ser/Cys & $14(70)$ & $25(50)$ & $2.42(0.58-9.99)$ & 0.177 \\
\hline Cys/Cys & $3(15)$ & $12(24)$ & $1.09(0.29-4.08)$ & 0.588 \\
\hline Ser & $20(50)$ & $51(51)$ & $1.00 \mathrm{Ref}$ & \\
\hline Cys & $20(50)$ & $49(49)$ & $1.08(0.18-6.43)$ & 0.640 \\
\hline \multicolumn{5}{|c|}{ XRCC1-Arg194Trp } \\
\hline Arg/Arg & $5(25)$ & $15(30)$ & $1.00 \mathrm{Ref}$ & \\
\hline Arg/Trp & $12(60)$ & $19(38)$ & $1.89(0.54-6.57)$ & 0.479 \\
\hline $\operatorname{Trp} / \operatorname{Trp}$ & $3(15)$ & $16(32)$ & $0.56(0.11-2.77)$ & 0.377 \\
\hline Arg & $22(55)$ & $49(49)$ & $1.00 \operatorname{Ref}$ & \\
\hline $\operatorname{Trp}$ & $18(45)$ & $51(51)$ & $0.78(0.37-1.64)$ & 0.646 \\
\hline
\end{tabular}


Table $6 R A D 51, X R C C 2$, and $X R C C 3$ gene polymorphism and triple-negative breast cancer progression ${ }^{\mathrm{a}}$

\begin{tabular}{|c|c|c|c|c|c|c|}
\hline & \multicolumn{2}{|c|}{ TNBC patients $(n=70)$} & \multirow[t]{3}{*}{ OR $(95 \% \mathrm{CI})^{\mathrm{a}}$} & \multicolumn{2}{|c|}{ TNBC patients $(n=70)$} & \multirow[t]{3}{*}{ OR $(95 \% \mathrm{CI})^{\mathrm{b}}$} \\
\hline & \multicolumn{2}{|l|}{ Tumor size } & & \multicolumn{2}{|l|}{ Node status } & \\
\hline & $\begin{array}{l}\mathrm{T} 3+\mathrm{T} 4(N=22) \\
\text { Number }(\%)\end{array}$ & $\begin{array}{l}\mathrm{T} 1+\mathrm{T} 2(N=48) \\
\text { Number }(\%)\end{array}$ & & $\begin{array}{l}\mathrm{N}+(n=38) \\
\text { Number }(\%)\end{array}$ & $\begin{array}{l}\mathrm{N}-(n=32) \\
\text { Number }(\%)\end{array}$ & \\
\hline \multicolumn{7}{|c|}{ ERCC2-Lys751Gln } \\
\hline Lys/Lys & $1(5)$ & $9(19)$ & $1.00 \mathrm{Ref}$ & $5(13)$ & $5(16)$ & $1.00 \mathrm{Ref}$ \\
\hline Lys/Gln & $1(5)$ & $9(19)$ & $1.00(0.05-18.57)$ & $3(8)$ & $7(22)$ & $0.42(0.06-2.48)$ \\
\hline $\mathrm{Gln} / \mathrm{Gln}$ & $20(90)$ & $30(62)$ & $6.00(0.70-51.10)$ & $30(79)$ & $20(32)$ & $1.50(0.38-5.85)$ \\
\hline Lys & $3(7)$ & $27(28)$ & $1.00 \mathrm{Ref}$ & $13(17)$ & $17(27)$ & $1.00 \mathrm{Ref}$ \\
\hline Gln & $41(93)$ & $69(72)$ & $5.34(1.52-18.73)$ & $63(83)$ & $47(73)$ & $1.75(0.77-3.96)$ \\
\hline \multicolumn{7}{|c|}{$h O G G 1$-Ser326Cys } \\
\hline Ser/Ser & $7(32)$ & $9(19)$ & 1.00 Ref & $11(29)$ & $5(16)$ & $1.00 \mathrm{Ref}$ \\
\hline Ser/Cys & $8(36)$ & $31(64)$ & $0.33(0.09-1.16)$ & $16(42)$ & $23(72)$ & $0.31(0.09-1.38)$ \\
\hline Cys/Cys & $7(32)$ & $8(17)$ & $1.12(0.27-4.63)$ & $11(29)$ & $4(12)$ & $1.25(0.26-5.93)$ \\
\hline Ser & $22(50)$ & $49(51)$ & 1.00 Ref & $38(50)$ & $33(52)$ & 1.00 Ref \\
\hline Cys & $22(50)$ & $47(49)$ & $1.04(0.51-2.12)$ & $38(50)$ & $31(48)$ & $1.06(0.54-2.07)$ \\
\hline \multicolumn{7}{|c|}{ XRCC1-Arg194Trp } \\
\hline Arg/Arg & $8(36)$ & $12(25)$ & 1.00 Ref & $12(32)$ & $8(25)$ & 1.00 Ref \\
\hline Arg/Trp & $9(41)$ & $22(46)$ & $0.61(0.18-2.00)$ & $14(36)$ & $17(53)$ & $0.54(0.17-1.71)$ \\
\hline $\operatorname{Trp} / \operatorname{Trp}$ & $5(23)$ & $14(29)$ & $0.53(0.13-2.08)$ & $12(32)$ & $7(22)$ & $1.14(0.41-4.16)$ \\
\hline Arg & $25(56)$ & $46(48)$ & $1.00 \mathrm{Ref}$ & $38(50)$ & $33(52)$ & 1.00 Ref \\
\hline $\operatorname{Trp}$ & $19(44)$ & $50(52)$ & $0.70(0.34-1.43)$ & $38(50)$ & $31(48)$ & $1.06(0.54-2.07)$ \\
\hline
\end{tabular}

${ }^{\mathrm{a}} \mathrm{T} 2$ vs. $\mathrm{T} 3+\mathrm{T} 4$

${ }^{\mathrm{b}} \mathrm{N}-$ (node negative) vs. $\mathrm{N}+$ (node positive)

gland, endometrium, bone, cardiovascular system, brain, and urogenital tract in men and women, with the intracellular estrogen functioning as a hormone-dependent transcriptional regulator. Estrogen metabolism in eukaryotic cells includes formation of a variety of intermediate forms and production of ROS [31].

BER is very important for repairing base damage induced by ROS. In our study, we analyzed the association between polymorphisms of two genes of BER and TNBC.

In the literature, much research suggests that Ser326Cys polymorphism of hOGG1 gene may contribute to mammary carcinogenesis [32-34]. However, the reported results have rather been inconsistent [35-37]. What is important is that recent reports introduce the role of Ser326Cys polymorphism in the development of TNBC [34].

In the recent studies, Ser326Cys polymorphism of $h O G G 1$ may be associated with an elevated tumor risk in the Chinese populations, regarding TNBC [28], while there are still no data, which would be illustrating the significance of $h O G G 1$ polymorphism for TNBC development in other populations. In the reported study, the Ser326Cys polymorphism of hOGG1 gene was not correlated with triple-negative breast carcinoma progression.
Literature data suggest a protective role of the $\operatorname{Trp} / \operatorname{Trp}$ genotype of the $\mathrm{Arg} / \mathrm{Trp}$ polymorphism of the $\mathrm{XRCCl}$ gene against the development of cancer, and this function can be underlined by increasing the activity of BER [27, 38]. In the literature, many reports confirm the significance of XRCC1 Arg194Trp polymorphism, regarding the risk of breast carcinoma [39-42]. This is not in agreement with our result. In the present work, no significant associations were observed between Arg194Trp genotype of XRCC1 and the incidence of TNBC in the Polish women.

In conclusion, in the present study, an association was identified between Lys751Gln polymorphism of ERCC2 and the incidence of TNBC. The obtained data suggest that the reported study may be the first observation of the polymorphisms in ERCC2, hOGG1, and $X R C C 1$ genes, involved in the DNA repair pathway, to be associated with triple-negative breast carcinoma risk in the population of Polish women. Further studies, conducted on a larger group, are suggested to clarify this point.

Conflicts of interest None 
Open Access This article is distributed under the terms of the Creative Commons Attribution License which permits any use, distribution, and reproduction in any medium, provided the original author(s) and the source are credited.

\section{References}

1. Ferlay J, Shin HR, Bray F, Forman D, Mathers C, Parkin DM. Estimates of worldwide burden of cancer in 2008: GLOBOCAN 2008. Int J Cancer. 2010;127:2893-917.

2. Bauer KR, Brown M, Cress RD, Parise CA, Caggiano V. Descriptive analysis of estrogen receptor (ER)-negative, progesterone receptor (PR)-negative, and HER2-negative invasive breast cancer, the socalled triple-negative phenotype: a population-based study from the California Cancer Registry. Cancer. 2007;109:1721-8.

3. Chacón RD, Costanzo MV. Triple-negative breast cancer. Breast Cancer Res. 2010;12:S3.

4. Cleator S, Heller W, Coombes RC. Triple-negative breast cancer: therapeutic options. Lancet Oncol. 2007;8:235-44.

5. Dawson SJ, Provenzano E, Caldas C. Triple negative breast cancers: clinical and prognostic implications. Eur J Cancer. 2009;45:27-40.

6. de Ruijter TC, Veeck J, de Hoon JP, van Engeland M, Tjan-Heijnen VC. Characteristics of triple-negative breast cancer. J Cancer Res Clin Oncol. 2011;137:183-92.

7. Hanawalt PC. Subpathways of nucleotide excision repair and their regulation. Oncogene. 2002;21:8949-56.

8. Wilson DM, Bohr VA. The mechanics of base excision repair, and its relationship to aging and disease. DNA Repair (Amst). 2007;6:544 59.

9. Almeida KH, Sobol RW. A unified view of base excision repair: lesion-dependent protein complexes regulated by post-translational modification. DNA Repair (Amst). 2007;6:695-711.

10. Xue X, Yin Z, Lu Y, Zhang H, Yan Y, Zhao Y, et al. The joint effect of hOGG1, APE1, and ADPRT polymorphisms and cooking oil fumes on the risk of lung adenocarcinoma in Chinese non-smoking females. PLoS One. 2013;8:e71157.

11. Wang W, Dang S, Li Y, Sun M, Jia X, Wang R, et al. hOGG1 Ser326Cys polymorphism and risk of hepatocellular carcinoma among East Asians: a meta-analysis. PLoS One. 2013;8:e60178.

12. Zhu S, Zhang H, Tang Y, Wang J. Polymorphisms in XPD and hOGG1 and prostate cancer risk: a meta-analysis. Urol Int. 2012;89:233-40.

13. Mao Y, Xu X, Lin Y, Chen H, Wu J, Hu Z, et al. Quantitative assessment of the associations between XRCC1 polymorphisms and bladder cancer risk. World J Surg Oncol. 2013;11:58.

14. Kohno T, Kunitoh H, Toyama K, Yamamoto S, Kuchiba A, Saito D, et al. Association of the OGG1-Ser326Cys polymorphism with lung adenocarcinoma risk. Cancer Sci. 2006;97:724-28.

15. Pachouri SS, Sobti RC, Kaur P, Singh J. Contrasting impact of DNA repair gene XRCC1 polymorphisms Arg399Gln and Arg194Trp on the risk of lung cancer in the north-Indian population. DNA Cell Biol. 2007;26:186-91.

16. Poplawski T, Arabski M, Kozirowska D, Blasinska-Morawiec M, Morawiec Z, Morawiec-Bajda A, et al. DNA damage and repair in gastric cancer-a correlation with the hOGG1 and RAD51 genes polymorphisms. Mutat Res. 2006;601:83-91.

17. Yin J, Vogel U, Ma Y, Qi R, Sun Z, Wang H. The DNA repair gene $\mathrm{XRCC} 1$ and genetic susceptibility of lung cancer in a northeastern Chinese population. Lung Cancer. 2007;56:153-60.

18. Hatt L, Loft S, Risom L, Møller P, Sørensen M, Raaschou-Nielsen O, et al. OGG1 expression and OGG1 Ser326Cys polymorphism and risk of lung cancer in a prospective study. Mutat Res. 2008;639:45-54.
19. Yin J, Vogel U, Ma Y, Guo L, Wang H, Qi R. Polymorphism of the DNA repair gene ERCC2 Lys751Gln and risk of lung cancer in a northeastern Chinese population. Cancer Genet Cytogenet. 2006;169:27-32.

20. De Ruyck K, Szaumkessel M, De Rudder I, Dehoorne A, Vral A, Claes $\mathrm{K}$, et al. Polymorphisms in base-excision repair and nucleotide-excision repair genes in relation to lung cancer risk. Mutat Res. 2007;631:101-10.

21. Brewster AM, Jorgensen TJ, Ruczinski I, Huang HY, Hoffman S, Thuita L, et al. Polymorphisms of the DNA repair genes ERCC2 (Lys751Gln) and XRCC1 (Arg399Gln and Arg194Trp): relationship to breast cancer risk and familial predisposition to breast cancer. Breast Cancer Res Treat. 2006;95:73-80.

22. Patel AV, Calle EE, Pavluck AL, Feigelson HS, Thun MJ, Rodriguez C. A prospective study of XRCC1 (X-ray cross-complementing group 1) polymorphisms and breast cancer risk. Breast Cancer Res. 2005;7:116873.

23. Bewick MA, Lafrenie RM, Conlon MS. Nucleotide excision repair polymorphisms and survival outcome for patients with metastatic breast cancer. J Cancer Res Clin Oncol. 2011;137:543-50.

24. Ming-Shiean H, Yu JC, Wang HW, Chen ST, Hsiung CN, Ding SL, et al. Synergistic effects of polymorphisms in DNA repair genes and endogenous estrogen exposure on female breast cancer risk. Ann Surg Oncol. 2010;17:760-71.

25. Abdel-Rahman SZ, El-Zein RA. The 399Gln polymorphism in the DNA repair gene XRCC1 modulates the genotoxic response induced in human lymphocytes by the tobacco-specific nitrosamine NNK. Cancer Lett. 2000;159:63-71.

26. Vodicka P, Stetina R, Polakova V, Tulupova E, Naccarati A, Vodickova L, et al. Association of DNA repair polymorphisms with DNA repair functional outcomes in healthy human subjects. Carcinogenesis. 2007;28:657-64.

27. Wang Y, Spitz MR, Zhu Y, Dong Q, Shete S, Wu X. From genotype to phenotype: correlating XRCC1 polymorphisms with mutagen sensitivity. DNA Repair. 2003;2:901-8.

28. Silva SN, Moita R, Azevedo AP, Gouveia R, Manita I, Pina JE, et al. Menopausal age and XRCC1 gene polymorphisms: role in breast cancer risk. Cancer Detect Prev. 2007;31:303-9.

29. Stern MC, Conway K, Li Y, Mistry K, Taylor JA. DNA repair gene polymorphisms and probability of TP53 mutation in bladder cancer. Mol Carcinog. 2006;45:715-9.

30. Applebaum KM, Karagas MR, Hunter DJ, et al. Polymorphisms in nucleotide excision repair genes, arsenic exposure, and nonmelanoma skin cancer in New Hampshire. Environ Health Perspect. 2007;115:1231-6.

31. Martucci CP, Fishman J. P450 enzymes of estrogen metabolism. Pharmacol Ther. 1993;57:237-57.

32. Yuan W, Xu L, Feng Y, Yang Y, Chen W, Wang J, et al. The hOGG1 Ser326Cys polymorphism and breast cancer risk: a meta-analysis. Breast Cancer Res Treat. 2010;122:835-42.

33. Choi JY, Hamajima N, Tajima K, Yoo KY, Yoon KS, Park SK, et al. hOGG1 Ser326Cys polymorphism and breast cancer risk among Asian women. Breast Cancer Res Treat. 2003;79:59-62.

34. Xie H, Xia K, Rong H, Chen X. Genetic polymorphism in hOGG1 is associated with triple-negative breast cancer risk in Chinese Han women. Breast. 2013;22:707-12.

35. Ding DP, Zhang Y, He XF. Lack of association between hOGG1 Ser326Cys polymorphism and breast cancer susceptibility in European population. Breast Cancer Res Treat. 2011;129:1023-6.

36. Gu D, Wang M, Zhang Z, Chen J. Lack of association between the hOGG1 Ser326Cys polymorphism and breast cancer risk: evidence from 11 case-control studies. Breast Cancer Res Treat. 2010;122:527-31.

37. Romanowicz-Makowska H, Smolarz B, Makowski M, Połać I, Pertyński T. Ser326Cys polymorphism in DNA repair genes hOGG1 in breast cancer women. Pol J Pathol. 2008;59:201-4.

38. Tuimala J, Szekely G, Gundy S, Hirvonen A, Norppa H. Genetic polymorphisms of DNA repair and xenobiotic-metabolizing enzymes: role in mutagen sensitivity. Carcinogenesis. 2002;23:1003-8. 
39. Al Mutairi FM, Alanazi M, Shalaby M, Alabdulkarim HA, Pathan AA, Parine NR. Association of XRCC1 gene polymorphisms with breast cancer susceptibility in Saudi patients. Asian Pac J Cancer Prev. 2013;14:3809-13.

40. Przybylowska-Sygut K, Stanczyk M, Kusinska R, Kordek R, Majsterek I. Association of the Arg194Trp and the Arg399Gln polymorphisms of the XRCC1 gene with risk occurrence and the response to adjuvant therapy among Polish women with breast cancer. Clin Breast Cancer. 2013;13:61-8.

41. Saadat M. Haplotype analysis of XRCC1 (at codons 194 and 399) and susceptibility to breast cancer, a meta-analysis of the literatures. Breast Cancer Res Treat. 2010;124:785-91.

42. Li H, Ha TC, Tai BC. XRCC1 gene polymorphisms and breast cancer risk in different populations: a meta-analysis. Breast. 2009;18:183-91. 